\title{
Climate change in the Mackenzie Mountains, N.W.T., Canada
}

\author{
Linheng Liang*, G. Peter Kershaw** \\ Department of Geography, University of Alberta, Edmonton, Alberta, Canada T6G 2H4
}

\begin{abstract}
It has been asserted that climate change will be most expressed at high latitudes. To test whether recent climate records contain evidence of change several northern stations were analyzed in and adjacent to the Mackenzie Mountains, N.W.T., Canada. It was found that the mean annual air temperature increased by $3.6^{\circ} \mathrm{C}(1968$ to 1992$)$ at Ross River, $1.6^{\circ} \mathrm{C}(1974$ to 1982$)$ at Tsichu River, $1.8^{\circ} \mathrm{C}$ (1966 to 1990$)$ at Tungsten and $0.9^{\circ} \mathrm{C}$ (1943 to 1992) at Norman Wells. The Norman Wells temperature rise was less than the other stations, however after 1980 the rise was of a greater magnitude. The magnitude of mean annual temperature rise increased from east to west over the $500 \mathrm{~km}$ between the most distant stations. Mean summer rainfall for Ross River, Tungsten, Tsichu River and Sheldon Lake increased by $6,86,51$, and $50 \mathrm{~mm}$, respectively. Norman Wells rainfall decreased by about $42 \mathrm{~mm}$. Annual rainfall, snowfall and precipitation were relatively stable at Ross River, but decreased by about $36 \mathrm{~mm}$ (1962 to 1992) at Norman Wells. For Tungsten, over the period from 1960 to 1991, it increased by about $250 \mathrm{~mm}$. Results from an Autoregressive Integrated Moving Average model suggest that the mean annual air temperatures at Norman Wells and Ross River over the next 5 to 8 yr will be consistent with the changing trends of temperatures since 1980; this will result in a shortening of the winter season. The predicted precipitation at these 2 stations has the same trend, initially a slight decrease followed by an increase. Predictions for rainfall indicate no change at Ross River, but at Norman Wells an initially large decrease will be followed by an increase. Snowfall is predicted to increase greatly at Norman Wells over the next 8 yr. At Ross River, snowfall is predicted to increase after 1993.
\end{abstract}

KEY WORDS: Climate change $\cdot$ Climate prediction $\cdot$ Mountain climate $\cdot$ Northern Canada

\section{INTRODUCTION}

In Canada, the mean annual national temperature over the past century has risen by $1.1^{\circ} \mathrm{C}$, and significant increases in minimum temperatures and decreases in mean temperature range have been documented in the western and eastern continental regions (Skinner \& Gullett 1993). According to the projections of Hansen et al. (1984) for a $2 \times \mathrm{CO}_{2}$ (i.e. double the present $\mathrm{CO}_{2}$ concentration) climate, winter temperatures are predicted to increase much more than summer temperatures, with some changes exceeding $10^{\circ} \mathrm{C}$ for the western Canadian Arctic. Increases might be only 2 to $3^{\circ} \mathrm{C}$ in summer. Increases of 10 to $50 \%$ in summer

\footnotetext{
- Visiting scholar, Lanzhou Institute of Glaciology and Geocryology, Chinese Academy of Sciences, Lanzhou, Gansu, 730000, China

- Addressee for correspondence
}

precipitation and as much as $60 \%$ in winter were predicted for parts of the western Canadian Arctic.

Few studies have considered the implications of climate change on a regional basis for northern areas. There are regional climate descriptions for the Mackenzie Valley (Burns 1974) and for the Yukon (Wahl et al. 1987) but little discussion of the impacts of climate change (Lonergan \& Woo 1989, Gullett \& Skinner 1992). Furthermore, the Mackenzie Mountains (straddling the Yukon/NWT border) are largely undescribed climatically and little has been done with the limited data that are available to discover if there is evidence of climate change. Stuart \& Judge (1991) used 3 General Circulation Models (GCMs) to reproduce the present temperature and precipitation of the Mackenzie Valley. All methods were found to generate large errors with differences as much as $5^{\circ} \mathrm{C}$ between modelled and observed temperatures, and between one model and another over relatively large 
areas. Little faith can therefore be placed at present in the fine scale detail of GCM projections, and climate change impact analysis on the small scale may be confined to considering a variety of scenarios of climatic parameters.

The objective of this study was to provide a description of the climate in the Mackenzie Mountains and to assess the data base to determine if there is evidence for climate change in the mountains. To accomplish this 5 stations in or around the Mackenzie Mountains were selected for analysis of recent climate patterns and to predict near-future changes.

\section{LOCATION AND CHARACTERISTICS OF STATIONS}

The northernmost station used for the analysis was Norman Wells while the southernmost was Tungsten (Fig. 1). Vegetation in the area of the weather stations differed due to variations in elevation and latitude/longitude (Ecoregions Working Group 1989) (Table 1). As elevation increases, the dominant vegetation type changes from white spruce and subalpine fir forests to alpine shrub tundra. The climate of Ross River is dominated by Pacific air masses while that of Norman Wells is heavily influenced by air masses originating over the Beaufort Sea (Wahl et al. 1987). Tungsten and Tsichu River would most typify the climate of the Mackenzie Mountains.

The remoteness of the region and the sparse population restrict the number of reporting stations. The only permanent stations occur where communities exist. In 1990 Tungsten closed and the station was abandoned. The Tsichu River station operated continuously for $8 \mathrm{yr}$ but was closed in 1982. Sheldon Lakes is associated with the road maintenance camp at Twin Creeks and since the road is only open in summer, no record of winter conditions exists. Norman Wells was selected because of its proximity to the eastern border of the Mackenzie Mountains (i.e. $25 \mathrm{~km}$ ) and because it had one of the longest records in northwestern Canada. Ross River was selected since it lies the closest to the western edge of the Mackenzie Mountains on a transect bisecting the mountains through their widest extent from Norman Wells. Tungsten and Tsichu River are within the mountains on the border between the Selwyn and Mac- kenzie Mountains. Other stations such as Faro, Fort Good Hope, Fort Norman, Nahanni Butte, Watson Lake and Wrigley were either outside the mountains, had significant problems with record gaps, or were geographically unrepresentative of the study area (i.e. too far south or north)

\section{METHODS AND MODEL}

Data used in the analysis were calculated from daily data for air mean, maximum and minimum temperature, rainfall, snowfall, precipitation and snow on the ground. Statistical methods, such as moving average, linear regression and statistical tests, were used to analyze the changes and the trends of the observed data for the stations and, at the same time, the significance of the linear regression was tested with the $F$ ratio test of variance. All the F-tests were based on a $95 \%$ confidence interval.

SYSTAT (Wilkinson 1990) was used to predict changing trends in climate for Norman Wells and Ross

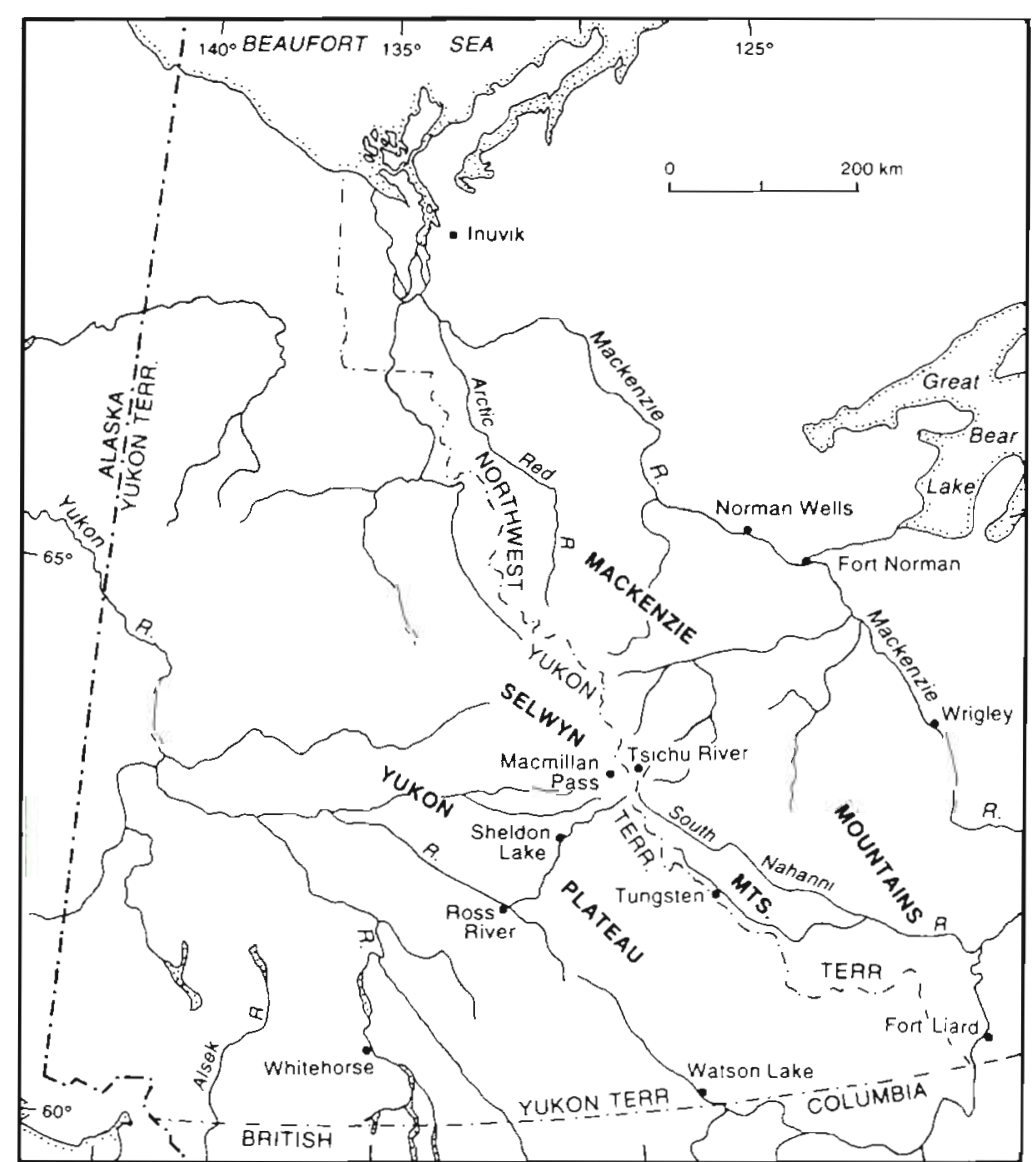

Fig. 1. The study area encompasses the Mackenzie and Selwyn Mountains in the N.W.T., Canada 
Table 1 Weather station characteristics

\begin{tabular}{|c|c|c|c|c|c|}
\hline Station & $\begin{array}{l}\text { Lat. } \\
\text { Long. }\end{array}$ & $\begin{array}{l}\text { Elevation } \\
\text { (m asl) }\end{array}$ & $\begin{array}{l}\text { Ecoclimatic } \\
\text { region }{ }^{a}\end{array}$ & Vegetation zone & $\begin{array}{l}\text { Record } \\
\text { period }\end{array}$ \\
\hline $\begin{array}{l}\text { Norman } \\
\text { Wells }\end{array}$ & $\begin{array}{l}65^{\circ} 17^{\prime} \mathrm{N} \\
126^{\circ} 48^{\prime} \mathrm{W}\end{array}$ & 67 & $\begin{array}{l}\text { Low } \\
\text { Subarctic }\end{array}$ & $\begin{array}{l}\text { Subarctic spruce forest: } \\
\text { black spruce, with understorey of dwarf } \\
\text { birch, labrador tea, lichen and feathermoss }\end{array}$ & $1946-1992$ \\
\hline $\begin{array}{l}\text { Ross } \\
\text { River }\end{array}$ & $\begin{array}{l}61^{\circ} 58^{\prime} \mathrm{N} \\
132^{\circ} 26^{\prime} \mathrm{W}\end{array}$ & 705 & $\begin{array}{l}\text { Boreal } \\
\text { Northern } \\
\text { Cordilleran }\end{array}$ & $\begin{array}{l}\text { Boreal spruce forest: } \\
\text { white spruce with understorey of juniper } \\
\text { and alder, extensive dry slopes with aspen } \\
\text { groves, grass and sage ground cover }\end{array}$ & $1967-1992$ \\
\hline $\begin{array}{l}\text { Sheldon } \\
\text { Lake }\end{array}$ & $\begin{array}{l}62^{\circ} 37^{\prime} \mathrm{N} \\
131^{\circ} 17^{\prime} \mathrm{W}\end{array}$ & 884 & $\begin{array}{l}\text { Subalpine } \\
\text { Northern } \\
\text { Cordilleran }\end{array}$ & $\begin{array}{l}\text { Boreal spruce forest: } \\
\text { white spruce with an understorey of moss } \\
\text { and lichen, subalpine fir with feathermoss } \\
\text { on slope }\end{array}$ & $1971-1992$ \\
\hline $\begin{array}{l}\text { Tsichu } \\
\text { River }\end{array}$ & $\begin{array}{l}63^{\circ} 17^{\prime} \mathrm{N} \\
130^{\circ} 49^{\prime} \mathrm{W}\end{array}$ & 1260 & $\begin{array}{l}\text { Alpine } \\
\text { Northern } \\
\text { Cordilleran }\end{array}$ & $\begin{array}{l}\text { Alpine shrub tundra: } \\
\text { dwarf birch with lichen and moss, willow } \\
\text { with moss in low sites }\end{array}$ & $1974-1982$ \\
\hline Tungsten & $\begin{array}{l}61^{\circ} 57^{\prime} \mathrm{N} \\
128^{\circ} 15^{\prime} \mathrm{W}\end{array}$ & 1143 & $\begin{array}{l}\text { Subalpine } \\
\text { Northern } \\
\text { Cordilleran }\end{array}$ & $\begin{array}{l}\text { Subalpine fir/spruce forest: } \\
\text { shrub birch and willow, with an } \\
\text { understorey of moss and lichen, and a } \\
\text { scattered cover of stunted trees, mainly } \\
\text { white spruce and subalpine fir }\end{array}$ & $1967-1989$ \\
\hline
\end{tabular}

River. On the basis of the data, the time domain BoxJenkins approach (Box \& Jenkins 1976) to the nonseasonal ARIMA (Auto-Regressive Integrated Moving Average) model of time series analysis in SYSTAT was employed. The ARIMA model and its application to the climatic data were as follows:

In order to understand the modelling procedure it is useful to briefly introduce the Autoregressive model. Given a data set of climatic variables $X_{1}, X_{2}, \ldots, X_{n}$, the Autoregressive models of order $p$, denoted $\operatorname{AR}(p)$, would be (Box \& Jenkins 1976):

$$
\begin{aligned}
X_{t} & =C+\varphi_{1} X_{t-1}+\varphi_{2} X_{t-2}+\ldots+\varphi_{t-p} X_{t-p}+a_{t} \\
t & =1,2, \ldots
\end{aligned}
$$

in which $C=\mu\left(1-\varphi_{1}-\varphi_{2}-\ldots-\varphi_{p}\right)$; or:

$$
\tilde{X}_{t}=\varphi_{1} \tilde{X}_{t-1}+\varphi_{2} \tilde{X}_{t-2}+\ldots+\varphi_{p} \tilde{X}_{t-p}
$$

where $t$ is year and $\left[a_{t}\right]$ is a sequence of uncorrelated errors with mean 0 , variance $\sigma^{2}$ and $\tilde{X}_{t}=X_{t}-\mu$. The constants $\varphi_{1}, \varphi_{2}, \ldots, \varphi_{p}, \mu$, and $\sigma^{2}$ are unknown and will be estimated from sample values $X_{1}, X_{2}, \ldots, X_{\mathrm{n}}$.

The combination of the model with the moving average model, $\operatorname{MA}(q)$, with the order of $q$,

$$
Z_{t}=\theta_{1} a_{t-1}+\theta_{2} a_{t-2}+\ldots+\theta_{q} a_{t-q}+a_{t}
$$

is the ARIMA model; the compact form of the model is

$$
\varphi(B) \nabla^{d} \tilde{X}_{t}=\theta(B) a_{t}
$$

where

$$
\begin{gathered}
\nabla^{d}=(1-B)^{d} \\
\varphi(B)=1-\varphi_{1} B-\varphi_{2} B^{2}-\ldots-\varphi_{p} B^{p} \\
\theta(B)=1-\theta_{1} B-\theta_{2} B^{2}-\ldots-\theta_{q} B^{q}
\end{gathered}
$$

The $d$ corresponds to the number of times the original data series has been differenced, $B$ is the backshift operator and the $\theta_{1}, \theta_{2}, \ldots, \theta_{q}$ are the $M A(q)$ coefficients. For details refer to Pankratz (1983) and BoraSenta \& Kounias (1980).

The application of the ARIMA model involves an iterative, 3-stage modelling procedure to determine predictions.

Identification. The univariate Box-Jenkins model (UBJ-ARIMA) requires stationary series. The stationary series have the following characteristics: (1) their mean, variance, and autocorrelation coefficients are essentially constant through time; (2) the estimated values meet the equation $\left|\varphi_{1}+\varphi_{2}+\ldots+\varphi_{n}\right|<1$; and (3) the autocorrelations of the series in ACF (autocorrelation-function) move rapidly toward zero. However, in practice most series are nonstationary, requiring a transformation to be converted into stationary series.

Two statistical and graphical devices were used during the identification stage to measure the correlation between the observations within a single data series. These devices were: an estimated ACF plot, and an estimated PACF (partial autocorrelation function) plot. 
The calculations require a set of $n$ time-sequenced observations on a single variable $\left(X_{1}, X_{2}, \ldots, X_{n}\right)$. The statistical relationship between pairs of observations separated by various time spans (year spans in our data) $\left(X_{t}, X_{t+k}\right), k=1,2, \ldots$ was evaluated by calculating the estimated autocorrelation and partial autocorrelation coefficients. These coefficients were displayed graphically in ACF and PACF plots. If the results met the stationary conditions, then it was possible to model and estimate the precise values of the parameters.

Estimation. ARIMA estimation is usually carried out on a computer using a nonlinear least-squares approach. The estimation of the climate parameters was carried out using SYSTAT. The method used was the least-squares criterion suggested by Box \& Jenkins (1976) in which least squares refers to the parameter estimates associated with the smallest sum of squared residuals (SSR). For ARIMA $(p, q)$, the SSR function produces a set of equations which are highly nonlinear and solvable only with a nonlinear, iterative search technique.

The estimation-stage results were used to check: (1) coefficients for stationarity and invertibility of series, (2) the coefficient quality which includes the statistical significance of estimated coefficient and standard error, correlation matrix and coefficient nearredundancy, and (3) closeness of fit - root-meansquared error and mean percent error.

Diagnostic checking. At this stage the estimated model is tested to determine if it is statistically adequate. If the model proves to be inadequate then the identification stage is revisited to tentatively select one or more other models. Also, diagnostic checking provides clues about how an inadequate model might be reformulated

The most important test of the statistical adequacy of an ARIMA model involves the assumption that the random shocks are independent, or not autocorrelated. The basic analytical tool is the residual ACF. The resid- ual ACF for a properly built ARIMA model will ideally have autocorrelation coefficients that are all near zero A t-test indicates if coefficients are significantly different from zero. In practice, if the absolute value of a residual ACF t-value is less than approximately 1.25 at lags 1, 2 and 3, and less than about 1.6 at large lags, it can be concluded that the random shocks at that lag are independent (Pankratz 1983). A chi-squared test could also be used. At a $95 \%$ confidence interval $(\alpha=0.05)$, the residual plots, ACF and PACF can automatically be calculated and drawn using the SYSTAT package.

Prediction. ARIMA modelling may be used to predict future values of climatic variables (time series). On the basis of the ARIMA model described above, $t$ would be the current time period and the future values of a series variable would be denoted by $X_{t+1}, l \geq 1$. Period $t$ is the forecast origin, and $l$ is the forecast lead time.

To judge the prediction, we need to know the prediction error variance and standard deviation, and then construct confidence intervals around each predicted point using a table of probability for standard normal deviations. Usually, we take an approximate $95 \%$ confidence interval around each point predicted using a table of probability for standard normal deviations.

The optional forecast from ARIMA would be one in which no other univariate predictions have a smaller mean-squared prediction error (MSE). In practice, ARIMA predictions are minimum MSE predictions only if the strategy of identification, estimation, and diagnostic checking is adequate to the problem at hand, and only if that strategy has been properly employed.

\section{RESULTS}

\section{Mean annual, minimum and maximum air temperature}

Mean annual, minimum and maximum air temperature changes for the entire record period at each

Table 2. Trends in the record of climatic parameters for stations in and around the Mackenzie Mountains. ND: no data available

\begin{tabular}{|c|c|c|c|c|c|c|}
\hline Station & $\begin{array}{c}\text { Mean } \\
\text { temperature }\left({ }^{\circ} \mathrm{C}\right)\end{array}$ & $\begin{array}{c}\text { Maximum } \\
\text { temperature }\left({ }^{\circ} \mathrm{C}\right)\end{array}$ & $\begin{array}{c}\text { Minimum } \\
\text { temperature }\left({ }^{\circ} \mathrm{C}\right)\end{array}$ & $\begin{array}{l}\text { Rain } \\
(\mathrm{mm})\end{array}$ & $\begin{array}{l}\text { Snow } \\
(\mathrm{cm})\end{array}$ & $\begin{array}{l}\text { Total precipitation } \\
(\mathrm{mm})\end{array}$ \\
\hline Norman Wells & +0.9 & +0.7 & $+1.0^{\circ}$ & -42 & +22 & -36 \\
\hline Ross River & $+3.6^{\circ}$ & $+1.9^{\circ}$ & $+4.9^{\circ}$ & +6.0 & +1.0 & +7.0 \\
\hline Sheldon Lake & ND & ND & ND & $+50^{\mathrm{b}}$ & ND & $\mathrm{ND}$ \\
\hline Tsichu River & +1.6 & +1.5 & +1.4 & +51 & +43 & +16 \\
\hline Tungsten & $+1.8^{\circ}$ & $+1.3^{\circ}$ & $+2.0^{\circ}$ & +86 & +159 & +245 \\
\hline \multicolumn{7}{|c|}{$\begin{array}{l}\text { - Statistically significant (based on F-test, } \alpha=0.05 \text { ) } \\
\text { a The datum form at Norman Wells was changed into the sum of rainfall and the water equivalent of snowfall after } 1962, \text { so } \\
\text { the data are not equivalent to the sum of rainfall and snowfall }(\mathrm{cm}) \\
{ }^{2} \text { The data for each year are from May to September }\end{array}$} \\
\hline
\end{tabular}




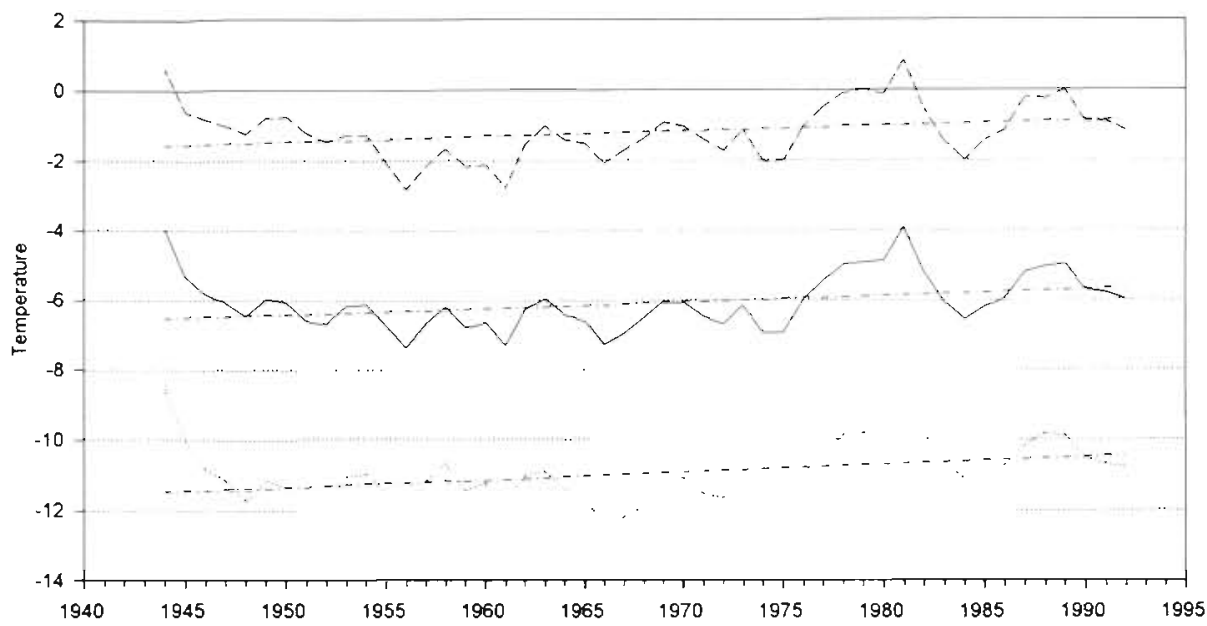

Fig. 2. Maximum, mean and minimum annual air temperatures $\left({ }^{\circ} \mathrm{C}\right)$ at Norman Wells $(3 \mathrm{yr}$ running mean) with linear fit line to illustrate trends

station were calculated (Table 2). However, the time periods of the data sets varied and this confounded interpretation of the trend analyses.

At Norman Wells, the mean annual, minimum and maximum temperatures clearly rose over the record period, with an overall increase of mean annual air temperature of about $0.9^{\circ} \mathrm{C}$, while annual maximum temperature rose $0.7^{\circ} \mathrm{C}$, and annual minimum temperature rose $1.0^{\circ} \mathrm{C}$ (Fig. 2).

The change in mean temperature for each station varied from 0.9 to $3.6^{\circ} \mathrm{C}$ (Fig. 3, Table 2). Increases in maximum temperatures were smaller than the increases in minimum temperatures. Norman Wells temperature changed least. The magnitude of the temperature increases at Norman Wells for the common period following 1968 was also the least among the sta- tions. Due to the limited time period covered by the Sheldon Lake and Tsichu River data it was not appropriate to evaluate trends. However, the data from these seasonal and short-term records did exhibit similar patterns to the other stations over the same time periods. Ross River experienced the greatest temperature rise.

\section{Temperature range}

An important characteristic of the data is how they vary. The air temperature range at Norman Wells and Ross River decreased over the record period (Figs. 4 \& 5). The decrease at Norman Wells was about $0.3^{\circ} \mathrm{C}$ (1944-92) and at Ross River $3.0^{\circ} \mathrm{C}$ (1968-92).

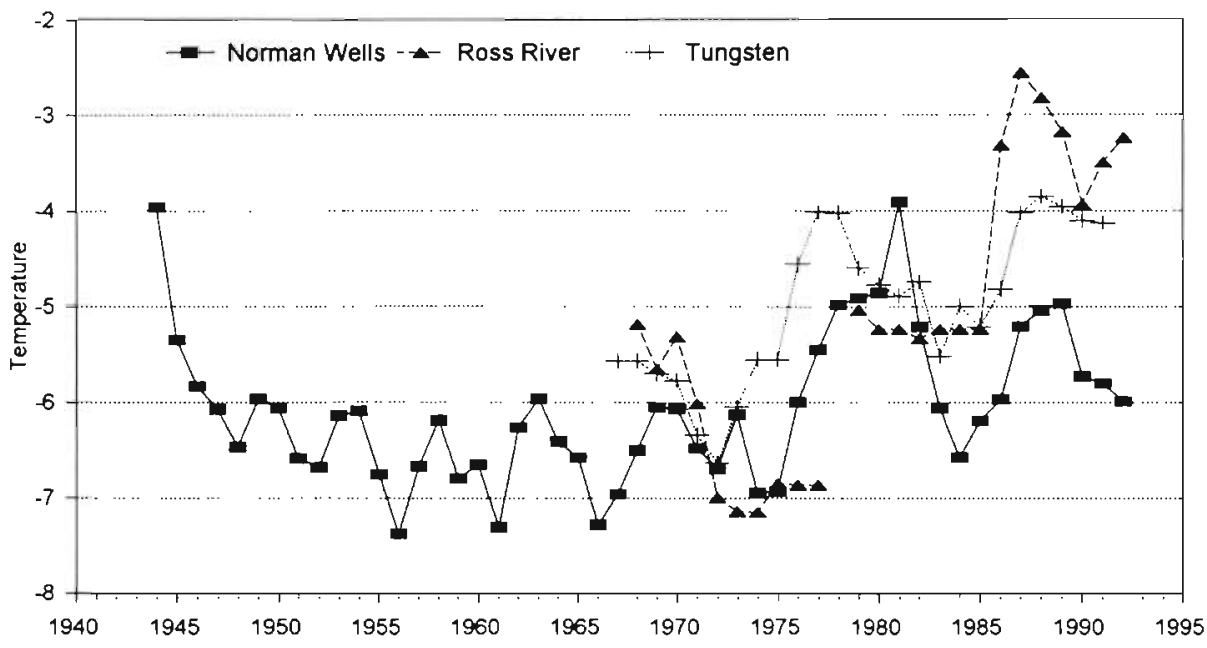

Fig. 3. Mean annual air temperatures $\left({ }^{\circ} \mathrm{C}\right)$ from stations relevant to the Mackenzie Mountains, N.W.T. Length of record periods varies and data gaps are shown 


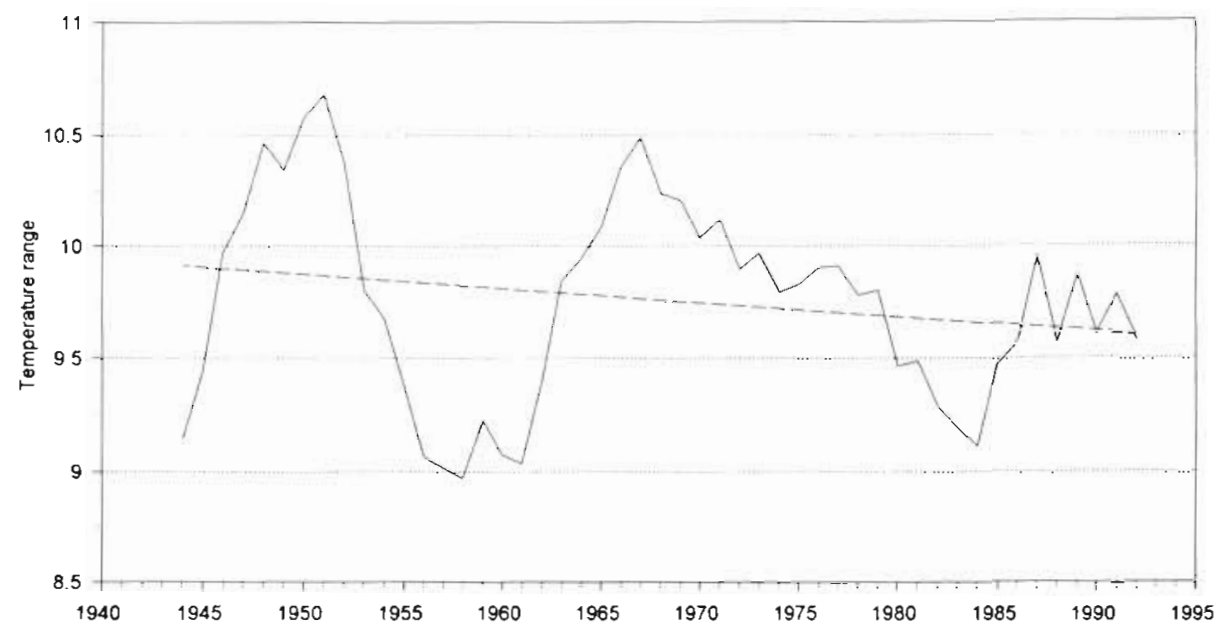

Fig. 4. Variation in annual temperature range $\left({ }^{\circ} \mathrm{C}\right)(3$ yr running mean) and the trend in the data over the record period at Norman Wells, N.W.T

\section{Rain, snow, precipitation and snow on ground}

Rainfall increased at 4 stations, although the record period at Tischu River was short (Table 2). At Norman Wells, in contrast, the rainfall decreased about $42 \mathrm{~mm}$. The increase of rainfall at Tungsten was the greatest of the 4 stations ( $86 \mathrm{~mm}$; Fig. 6A).

Snowfall at Norman Wells increased about $22 \mathrm{~cm}$ over the period of the record. There was a large increase, however, at the end of the 1980 s. The greatest rise in snowfall was at Tungsten, with an increase of $159 \mathrm{~mm}$ (Fig. 6B).

Total precipitation (rainfall plus snowfall) increased by $245 \mathrm{~mm}$ at Tungsten. The bulk of the increase was due to greater snowfall (Fig. 6). The precipitation at Norman Wells decreased. The recording of snowfall prior to 1962 was a depth measurement $(\mathrm{cm})$; since 1962 water equivalence (mm) was recorded. Consequently, the nature of the snowfall data varied over the record period making in-depth analysis impossible.

Snowfall and temperature at Norman Wells, and at Ross River, appear to be negatively related, although the relationships were not statistically significant (Figs. 7 \& 8).

Snow-on-ground data were complete only for Norman Wells. Based on these limited data the snowpack appears to have decreased since the 1950s. Snowpack variability also appears to have decreased (Fig. 9).

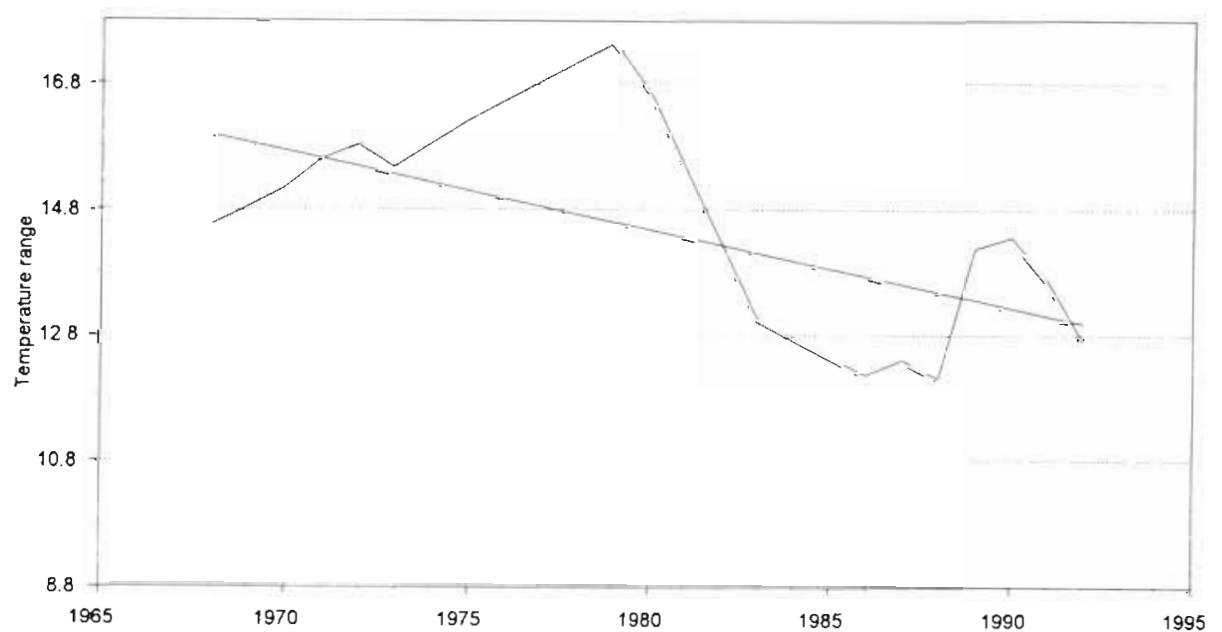

Fig. 5. Variation in annual temperature range $\left({ }^{\circ} \mathrm{C}\right)$ (3 yr running mean) and the trend in the data over the record period at Ross River, Yukon 

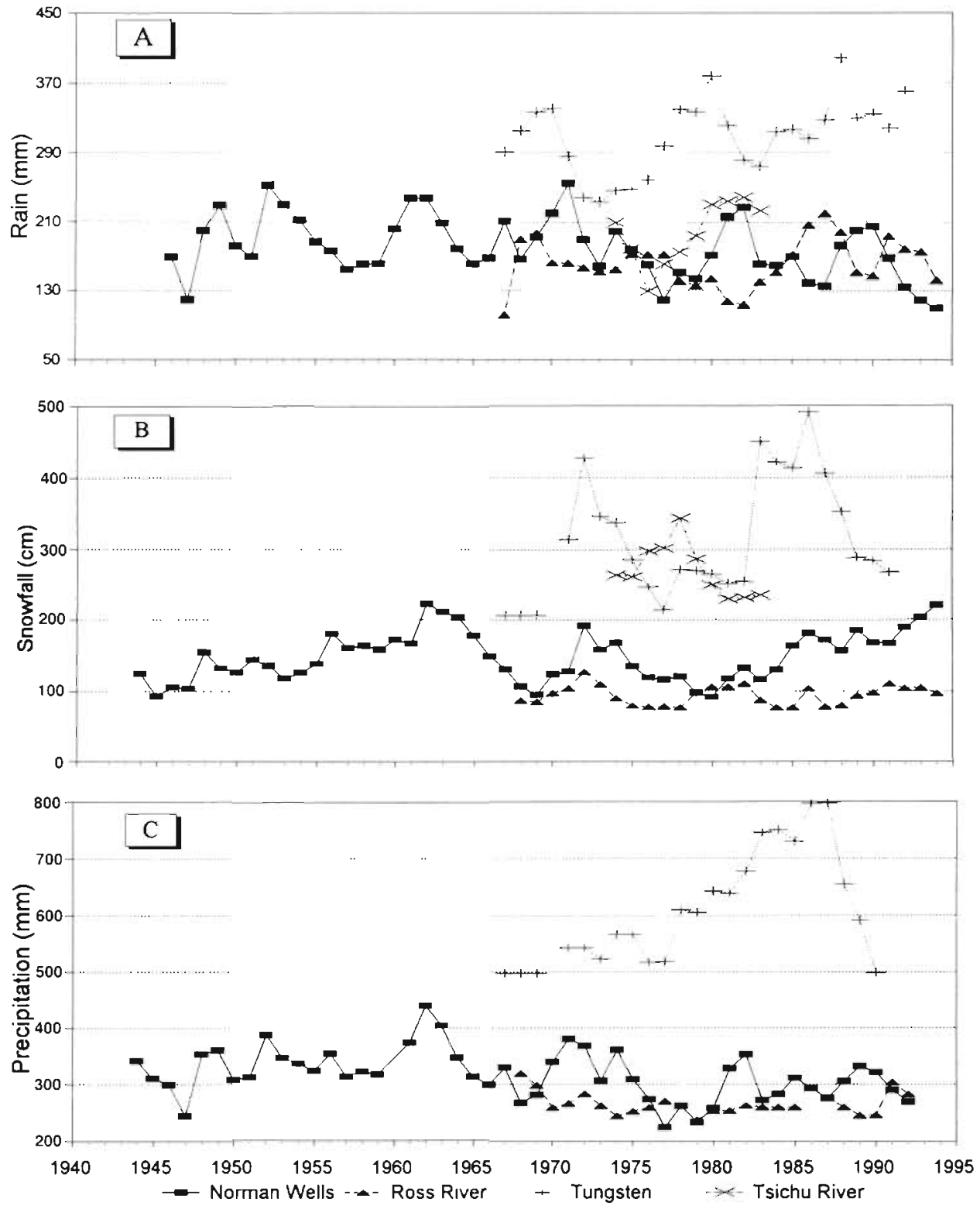

Fig. 6. Annual variations in (A) rain, (B) snow and (C) total precipitation (3 yr running mean) for 4 stations in the study area

\section{Near future climate predictions}

In order to get a sense of the changing trends and the variability of climate in the near future, a time series ARIMA model was applied. Stations with the longest climate data records were used - Norman Wells and Ross River.

Through preliminary ACF, PACF plots and estimates, it was determined that the data sets did not meet the requirement for stationary conditions. These analyses were also consistent with the actual trends observed in the data sets. Transformations, such as difference, smooth and trend, were therefore applied to the data. The ARIMA model $(A R=8$ and $M A=0)$ provided the best estimation and a stationary series for the air temperature data set at Norman Wells since: (1) the estimated SSR ('Sum of squares' in Table 3a) was constant; (2) the autocorrelation coefficients ('Parameter Values') were also constant after 8 iterations; (3) the estimated value (Table $3 \mathrm{~b})\left|\varphi_{1}+\varphi_{2}+\ldots+\varphi_{n}\right|=0.384$ $<1$, and (4) the autocorrelations in Fig. 10 rapidly moved toward zero.

The asymptotic standard error of the estimation (ASE) was quite small, and the largest was 0.219 ; based on a $95 \%$ confidence interval, the estimated value was well within the confidence limits; and the 


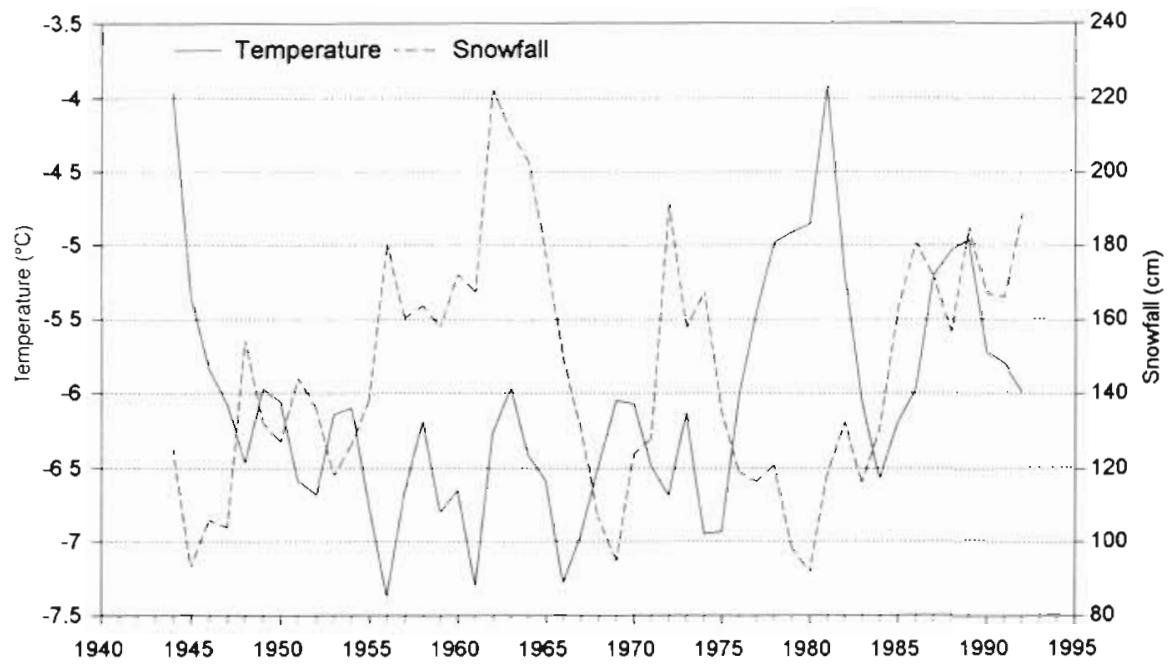

Fig 7. Companson of air temperature and snowfall at Norman Wells, N.W.T (3 yr running mean)

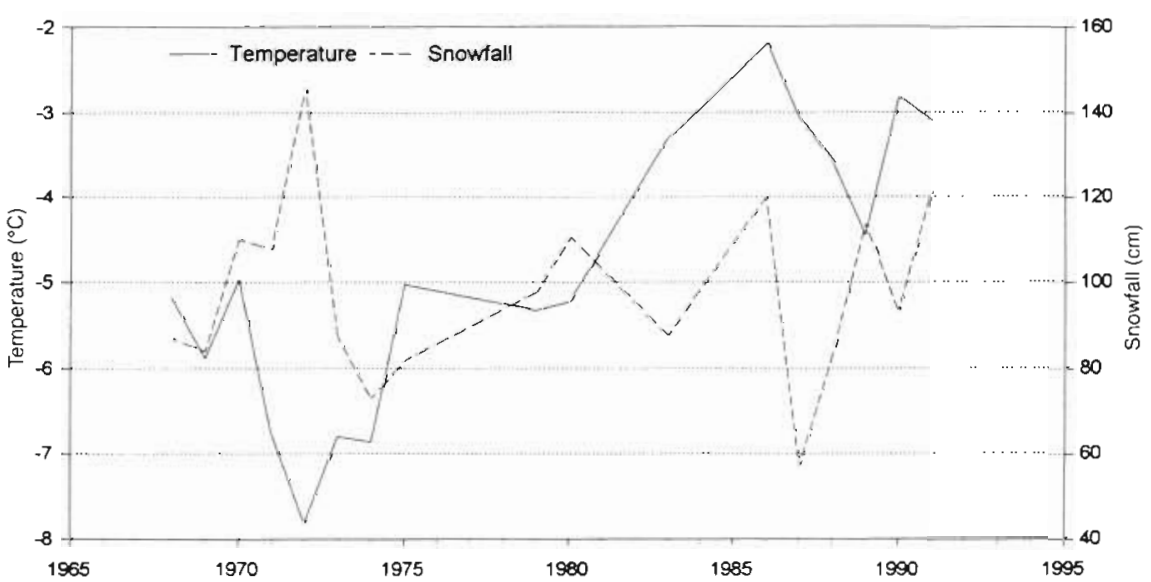

Flg 8. Companson of arr temperature and snowfall at Ross Ruver, Yukon (3 yr running mean)

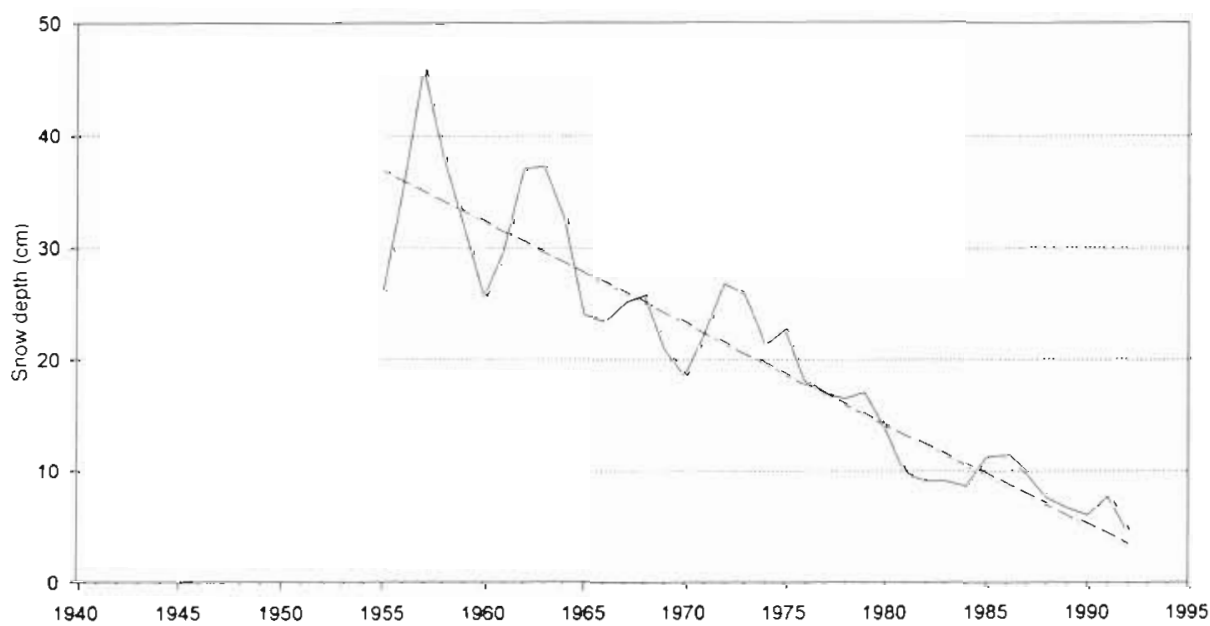

Fig 9 Snow on the ground at Norman Wells, N W T, and the linear fit for the 3 yr moving average plot 
Table 3. Estimate and prediction results of air temperature at Norman Wells

(a) Sum of square errors, parameter values estimated and final value of MSE

Iteration Sum of squares ${ }^{\star}$

Parameter values

\begin{tabular}{|c|c|c|c|c|c|c|c|c|c|}
\hline 0 & $1504961 D+02$ & 100 & 100 & 100 & 100 & 100 & 100 & 100 & 100 \\
\hline 1 & $1031784 D+02$ & .331 & -.038 & -.419 & -.035 & .007 & -.104 & -.200 & 145 \\
\hline 2 & $1000584 \mathrm{D}+02$ & .285 & -.030 & -.451 & .025 & .005 & -.189 & -.227 & 189 \\
\hline 3 & $.9940911 D+01$ & 258 & .082 & -.581 & .040 & .076 & -.265 & -.125 & 221 \\
\hline 4 & $.9923056 \mathrm{D}+01$ & .285 & .096 & -.584 & .059 & 131 & -.291 & -.135 & .209 \\
\hline 5 & $.9905578 \mathrm{D}+01$ & .310 & .096 & -.570 & .056 & 131 & -.305 & -.141 & 238 \\
\hline 6 & $.9886002 \mathrm{D}+01$ & 309 & .072 & -.573 & .064 & 132 & -.288 & -.155 & .262 \\
\hline 7 & $.9865146 \mathrm{D}+01$ & .294 & .070 & -.571 & .068 & .094 & -.278 & -.190 & .247 \\
\hline 8 & $.9858075 \mathrm{D}+01$ & 274 & .038 & -.565 & .050 & .075 & -.296 & -.192 & .225 \\
\hline 9 & $.9857098 D+01$ & 285 & .036 & -.570 & .060 & .066 & -.287 & -.187 & .222 \\
\hline 10 & $.9856761 D+01$ & .277 & .043 & -.569 & .046 & .074 & -.284 & -.198 & .228 \\
\hline 11 & $.9856424 D+01$ & .279 & .040 & -.570 & .051 & .073 & -.288 & -.194 & .226 \\
\hline 12 & $.9856423 \mathrm{D}+01$ & .279 & .040 & -.570 & .051 & .072 & -.288 & -.194 & .226 \\
\hline 13 & $.9856423 \mathrm{D}+01$ & .279 & .040 & -.570 & .051 & .072 & -.288 & -.194 & .226 \\
\hline 14 & $.9856423 \mathrm{D}+01$ & .279 & .040 & -.570 & .051 & .072 & -.288 & -.194 & .226 \\
\hline 15 & $9856423 D+01$ & .279 & .040 & -.570 & .051 & .072 & -.288 & -.194 & .226 \\
\hline
\end{tabular}

Final value of MSE is 0.246

(b) Estimated values and correlation matrix of parameters

\begin{tabular}{ccrcrr} 
Index & Type & Estimate & ASE & \multicolumn{2}{c}{$\begin{array}{c}\text { Limits at } 95 \% \text { confidence } \\
\text { Lower }\end{array}$} \\
\hline 1 & AR & 0.279 & 0.198 & -0.121 & 0.679 \\
2 & AR & 0.040 & 0.201 & -0.366 & 0.446 \\
3 & AR & -0.570 & 0.191 & -0.956 & -0.184 \\
4 & AR & 0.051 & 0.216 & -0.385 & 0.487 \\
5 & AR & 0.072 & 0.219 & -0.371 & 0.515 \\
6 & AR & -0.288 & 0.181 & -0.653 & 0.077 \\
7 & AR & -0.194 & 0.204 & -0.605 & 0.217 \\
8 & AR & 0.226 & 0.212 & -0.203 & 0.654
\end{tabular}

Asymptotic correlation matrix of parameters

\begin{tabular}{rrrrrrrrr} 
& 1 & 2 & 3 & 4 & 5 & 6 & 7 & 8 \\
\hline 1 & 1.000 & & & & & & & \\
2 & -0.056 & 1.000 & & & & & & \\
3 & 0.107 & -0.091 & 1.000 & & & & & \\
4 & 0.538 & 0.062 & -0.094 & 1.000 & & & & \\
5 & 0.071 & 0.527 & -0.001 & -0.139 & 1.000 & & & \\
6 & 0.085 & -0.069 & 0.417 & 0.015 & -0.163 & 1.000 & & \\
7 & 0.361 & 0.038 & -0.052 & 0.526 & 0.051 & -0.242 & 1.000 & \\
8 & 0.181 & 0.359 & 0.107 & 0.056 & 0.524 & 0.157 & 0.025 & 1.000
\end{tabular}

(c) Forecasted values

\begin{tabular}{|c|c|c|c|c|}
\hline Period $^{b}$ & $\begin{array}{l}\text { Lower limit at } \\
95 \% \text { confidence }\end{array}$ & Forecast & $\begin{array}{l}\text { Upper limit at } \\
95 \% \text { confidence }\end{array}$ & \\
\hline 50 & -6.616 & -5.643 & -4.670 & \\
\hline 51 & -7.708 & -6.129 & -4.549 & \\
\hline 52 & -7.775 & -5.691 & -3.607 & \\
\hline 53 & -7.786 & -5.536 & -3.286 & ${ }^{a} \mathrm{D}+02=10^{2}$ with ' $\mathrm{D}$ ' = double precision, \\
\hline 54 & -7.466 & -5.137 & -2.807 & similar to ' $E$ ' in math but the output \\
\hline 55 & -7.994 & -5.604 & -3.213 & digits are doubled \\
\hline 56 & -8.144 & -5.693 & -3.242 & b With 49 yr of data the forecasted values \\
\hline 57 & -8.443 & -5.961 & -3.478 & begin in Year 50 (1993) \\
\hline
\end{tabular}


(A) Plot of autocorrelations

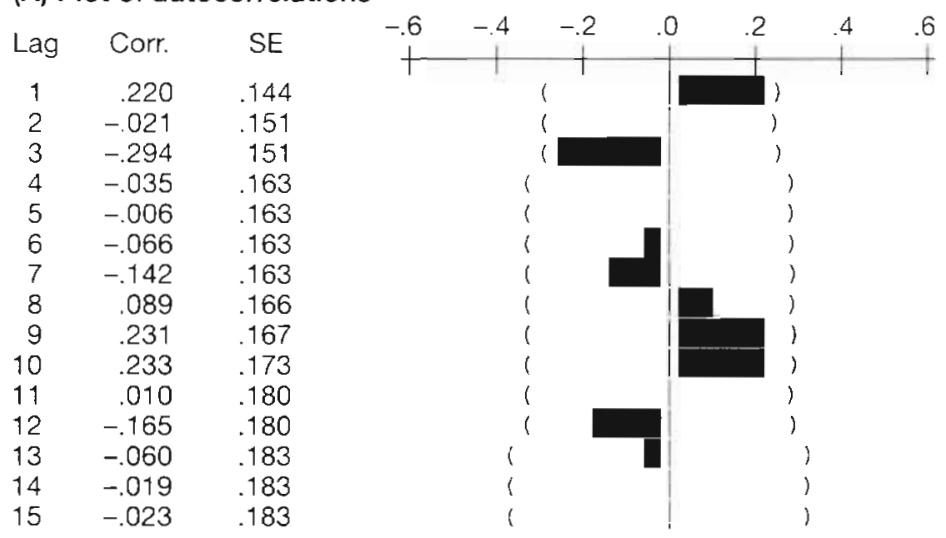

\section{(B) Plot of partial autocorrelations}

$\begin{array}{rrr}\text { Lag } & \text { Corr. } & \text { SE } \\ 1 & .220 & .144 \\ 2 & -.073 & .144 \\ 3 & -.288 & .144 \\ 4 & .105 & .144 \\ 5 & -.033 & .144 \\ 6 & -.171 & .144 \\ 7 & -.082 & .144 \\ 8 & .170 & .144 \\ 9 & .136 & .144 \\ 10 & .084 & .144 \\ 11 & .018 & .144 \\ 12 & -.087 & .144 \\ 13 & .065 & .144 \\ 14 & -.024 & .144 \\ 15 & -.056 & .144\end{array}$

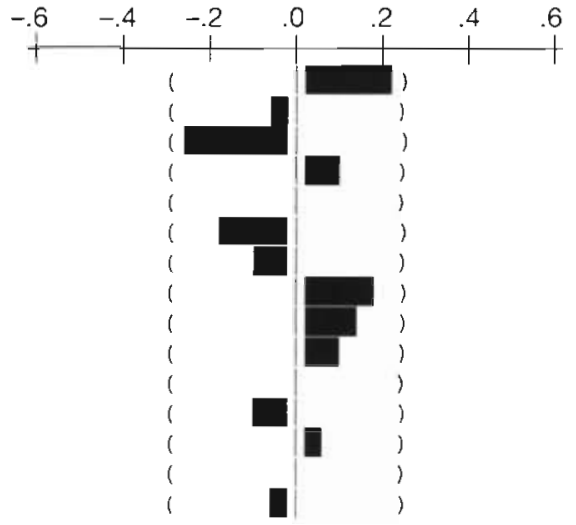

Fig. 10. Plot of (A) autocorrelation and (B) partial autocorrelation of air temperature data from Norman Wells, N.W.T. Vertical lines of parentheses delimit the $95 \%$ confidence limits, so all values lying within the brackets are significant at the 0.05 level. Number of cases $=48$, mean of series $=-0.065$, standard deviation of series $=0.536$

correlations between the estimated coefficients were not significant (the highest was less than 0.54) (Table 3b). The higher correlations between estimated coefficients suggest that the estimates were poor. Finally, the mean squared error (MSE) in this estimate was 0.246 , which was the smallest it could be adjusted to. The forecasted values and their $95 \%$ lower and upper limits are in Table 3c. All of these characteristics of the results indicate the prediction was valid.

The estimates of the coefficients don't mean the model was statistically adequate. The basic diagnosticchecking of the residual ACF and PACF (Fig. 10) indicates that the autocorrelation coefficients were statistically significant near zero, especially the first 3 coefficients which determine whether the estimation needs to be re-formulated.

The forecasting estimated in this data set was for 8 yr (Table 3c), and the back-casting was realistic for $7 \mathrm{yr}$ with significance and $95 \%$ upper and lower estimate limits, and in addition to the criteria in the modelling. It is possible to estimate a longer time period but there is a corresponding loss of accuracy, and therefore, the forecasted results are of less significance.

Based on the same principle, snowfall and rainfall at Norman Wells were estimated (Fig. 11). Some predictions were better than the one for temperature (e.g. snowfall with a MSE of 0.022) and the back-prediction was also good, which should be caused by the intrinsic characteristics of datasets.

A similar principle was applied to provide a 5-year forecasting and 3- or 4-year back-casting of the climatic data at Ross River (Fig. 12).

\section{DISCUSSION}

Changes in climatic variables over the record periods of each station had some common characteristics. There were strong trends of increasing temperatures at 4 stations (Sheldon Lake's record was too limited to test), and the increase of minimum temperatures was greater than that of maximum temperatures (except for the short record period at Tsichu River). These results correspond with Skinner \& Gullet's (1993) study. The precipitation in summer increased at all stations except at Norman Wells, but increased winter precipitation was the norm. Also, the total precipitation increased at all stations except Norman Wells. The Norman Wells results are at odds with the generally accepted assertion that summer precipitation will increase (e.g. Hansen et al. 1984)

Of the 5 stations, the greatest increase in snowfall and rainfall was at Tungsten. The greatest increase in air mean, maximum and minimum temperatures occurred at Ross River. The air temperature records over the common periods indicate that the temperatures before 1981 had comparatively similar amplitudes, but from 1981 to 1992, they clearly differed, with a sharp increase at Ross River but relatively stable conditions at Norman Wells (Fig. 3). The continuous and sharp decrease in snow on the ground at Norman Wells is potentially very significant, and it is difficult to identify the cause. According to the Climatological Station Catalogue in the Yukon and N.W.T. (1989), the station location has not changed. Perhaps the precipitous decline reflects microsite changes associated with construction and the urban build-up around the weather station instrument site and consequent modification of the wind regime. Given the magnitude of the change it is unlikely that it reflects the warming 

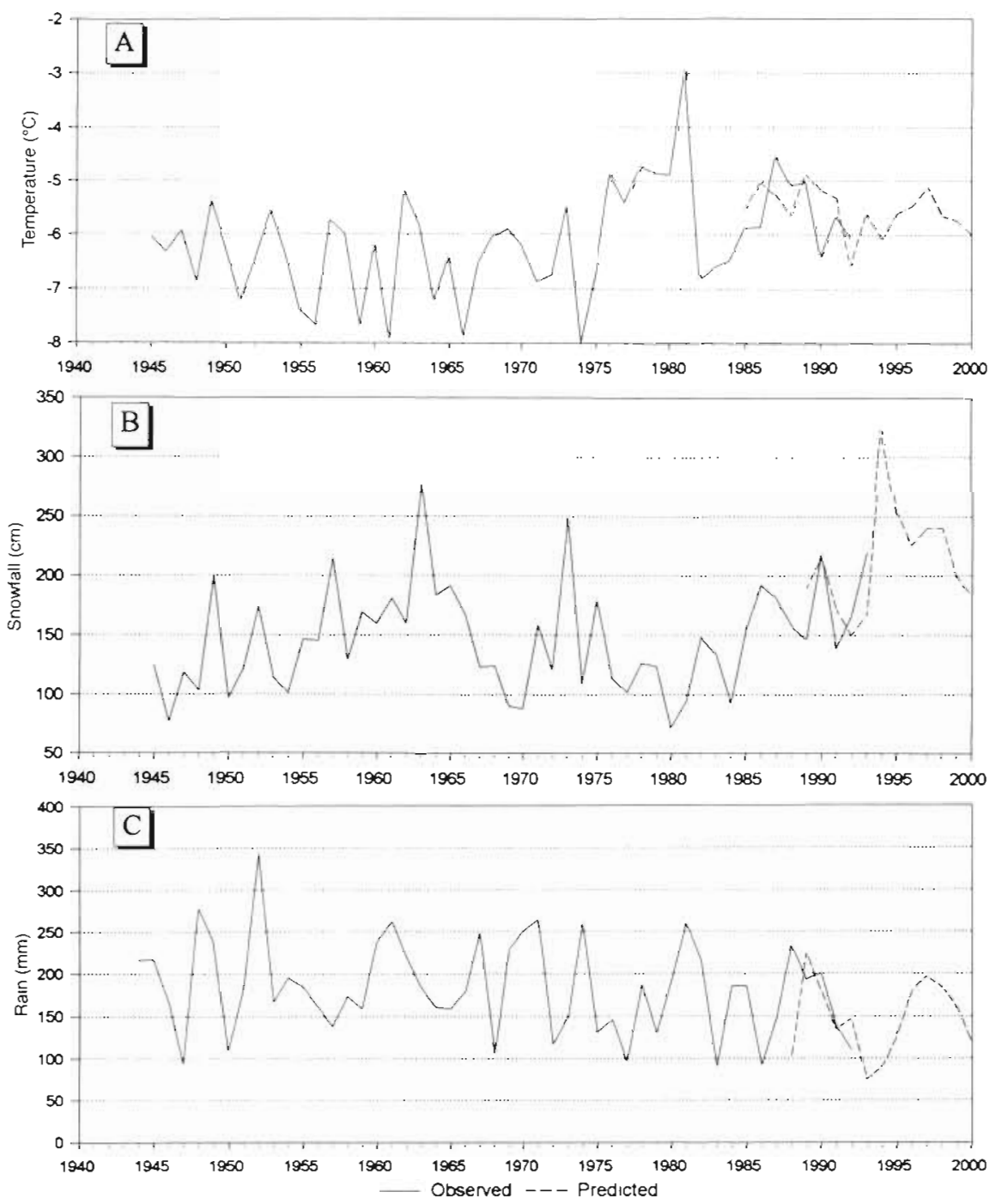

Fig. 11. Observed and predicted (A) air temperature, (B) snowfall and (C) rainfall for Norman Wells, N.W.T

trend in the Mackenzie mountains where a shortening of the winter period could result in less snow on the ground.

The temperature ranges at Norman Wells and Ross River appear to have varied with a periodicity of about 20 yr, with the amplitude at Norman Wells greater than at Ross River. The periodicity and amplitude should be controlled by macroclimatic process, such as features of atmospheric motion, etc. Ross River is more influenced by mild Pacific air masses, which would dampen the temperature variation, while Norman Wells would be affected by Arctic air masses that can cause extreme changes in climatic parameters over short time periods.

The predictions of climate variables for Norman Wells were significant, for example the estimation of increased snowfall with a MSE of 0.022 (indicating the excellent estimate quality). The back-casts were also significantly coincident with the observed data. The forecasted increase of snowfall in the future also corresponds with other studies (e.g. Hansen et al. 1984, Groisman \& Easterling 1994). The prediction is for snowfall to increase significantly, but for rainfall to decline (Fig. 11) at Norman Wells; the predicted precipitation at Ross River would not change greatly (Fig. 12), but no prediction of precipitation was made at Norman Wells because of the inconsistency in the data set resulting from a change in measurement technique instituted in 1962.

The prediction is for air temperature at Norman Wells to be stable to the end of this century at the relatively higher temperatures experienced after their large increases in the 1980s (Fig. 11). A similar situation was predicted for Ross River (Fig. 12). 

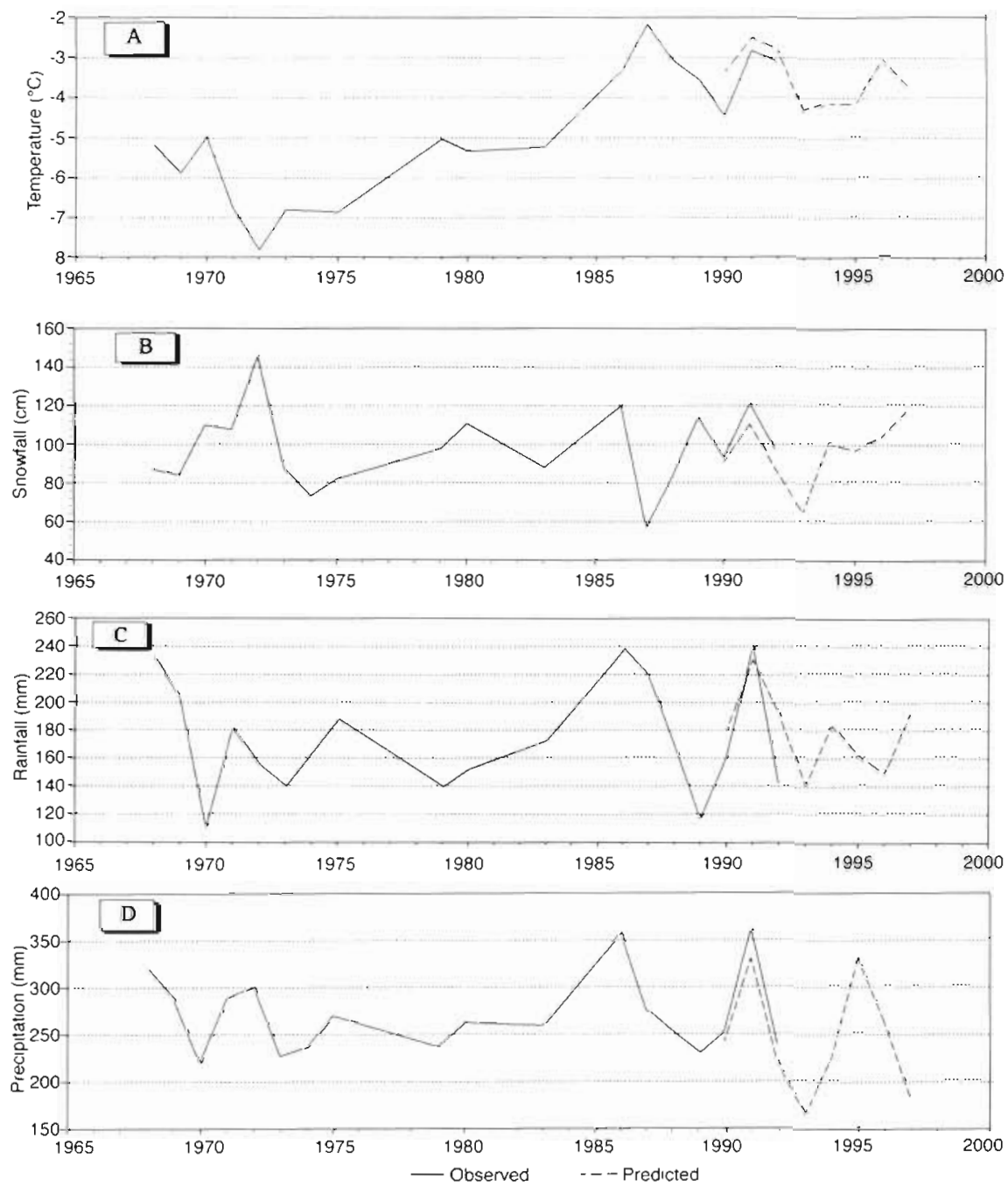

Fig. 12 Observed and predicted (A) alr temperature, (B) snowfall, (C) rainfall and (D) precipitation for Ross River, Yukon

The climate predictions for Ross River were also significant although precision declined toward the end of the predicted period. The reliable prediction penod of 5 yr for Ross River was shorter than for Norman Wells $(8 \mathrm{yr})$. Climatic parameters are expected to continue to vary over the prediction period (Figs. 11 \& 12).

It is critical to recognize that the predictions are based on exusting data. If the data are flawed then predictions will be questionable Furthermore, any stochastic events affectung the atmosphere can change the environmental context and fundamentally alter the climate, e.g. external climatological forcing factors, such as sea surface temperature anomalies like ENSO (El Niño-Southern Oscillation), or volcanic eruptıons (Groisman \& Easterling 1994)

The model used in this analysis is relatively new and complex; its wide use began in the 1980s where it was more often used in social and economic studies. Its application to climatic study appears to be appropriate and potentrally instructive in the context of regional climate change.

Increases un annual temperature and winter precipitation could be very significant to northern environments and human activities (Sneyers 1980). The actual impacts of climate change remain to be determined through field study. However, there are real trends apparent at the regional level, confirming that change is occurring.

Acknowledgements. Support for this paper was provided by Natural Sclences and Engineering Research Council of Canada, the Visiting Scholarship Program, the People's Republic of China and the Department of Geography, University of Alberta. Terry Thompson was instrumental at ferreting out data files and provided background on the stations included in the analysis. 


\section{LITERATURE CITED}

Bora-Senta E, Kounias S (1980) Parameter estimation and order determination of autoregressive models. In: Analyzing time series. Proceedings of the International Conference held on Guernsey, Channel Islands, October 1979 North-Holland Publishing Company, p 93-108

Box GEP, Jenkins GM (1976) Time series analys15: forecasting and control. Revised edition. Holden-Day, Inc, Oakland, CA

Burns BM (1972) The climate of the Mackenzie Valley Beaufort sea. Environment Canada. Vols 1 and 2. Climatological studies, no 24. Environment Canada, Toronto

Climatological Station Catalogue (1989) Atmospheric Environment Service, Prairie Provinces, Environment Canada Downsville, $O N$

Ecoregions Working Group, Canada Committee on Ecological Land Classification (1989) Ecoclimatic regions of Canada. Ecological Land Classification Series, No 23. Sustainable Development Branch, Canadian Wildlife Service, Environment Canada, Ottawa

Groisman PY, Easterling DR (1994) Variability and trends of total precipitation and snowfall over the United States and Canada. J Clim 7:184-205

Gullett DW, Skinner WR (1992) The state of Canada's climate: temperature change in Canada 1895-1991. State of the environment, Rep no 92-2. Minister of Supply and Service Canada, Atmospheric Environment Service, Environment Canada, Ottawa

Hansen JE, Lacis A, Rind D, Russell G, Stone P, Fung I, Ruedy $\mathrm{R}$, Lerner J (1984) Climate sensitivity: analysis of feedback mechanisms. In: Hansen J, Takahashi T (eds) Climate processes and climate sensitivity. Maqnice Ewing Series no 5, American Geophysical Union, Washington DC p $130-163$

Jones PD, Paper SCB, Bradley RS, Diaz HF, Kelly PM, Wigley TML (1986) Northern hemisphere surface air temperature variations: 1851-1984. J Clim appl Meteorol 25:161-179

Kane DL (1993) Northern hydrology and water resources in a changing environment. In: Impacts of climate change on resource management in the north. Fourth CanadaUnited States Symposium \& Biennial AES/DIAND meeting on northern climate. Department of Geography, University of Waterloo, Waterloo, p 55-67

Kauppi P (1985) Sensitivity of boreal forests to possible climatic warming. Clim Change 7:45-54

Kershaw GP, Skaret KD (1993) Microclimatic characteristics of palsas along an altitudinal gradient, Mackenzie Mountains, NWT, Canada. Sixth International Conference, Proceedings, Vol 1, p 338-343

Lawford RG (1990) Climate change and water supply and demand in western Canada. In: Climate change: implication for water and ecological resources. Proceedings of an international symposium/workshop. Department of Geography Publication Series Occasional Paper No 11, University of Waterloo, Waterloo, p 193-200

Lonergan S, Woo MK (1990) The impacts of climate warming on transportation in the Canadian Arctic. In: Actic and global change. Proceedings of the symposium on Arctic and global change, convened by the Climate Institute in cooperation with participating agencies and organizations. Climate Institute, Washington, DC, p 81-95
Manabe S, Slouffer RJ (1980) Sensitivity of global climate model to an increase of $\mathrm{CO}_{2}$ concentration in the atmosphere. J geophys Res 85:5529-5554

Meehl GA, Washington WM (1990) Climate sensitivity and snow-sea-ice albedo parameterization in an atmosphere GCM coupled to a mixed-layer ocean model. Clim Change 16:283-306

Pankratz A (1983) Forecasting with unıvariate Box-Jenkins models. Concepts and cases. Chaps 5-8. John Wiley \& Sons, lnc, New York

Riseborough DW, Smith MW (1993) Modelling permafrost response to climate change and climate variability. In Lunardini VJ, Bowen SL (eds) Proceedings Fourth International Symposium on Thermal Engineering and Science for Cold Regions Research, 28 Sept-1 Oct, 1993. CRREL, Special Report 93-22. US Army Cold Regions and Engineering $\mathrm{Lab}$, Hanover, $\mathrm{NH}$, p 179-187

Rivers R, Tate D (1990) Water demand management: a policy response to climate change. In: Climate change: implication for water and ecological resources. Proceedings of an international symposium/workshop. Department of Geography Publication Series Occasional Paper No 11, University of Waterloo, Waterloo, p 188-191

Rowe S, Rizzo B (1990) How climate affects ecosystems - a Canadian perspective on what we know. In: Climate change: implications for water and ecological resources Proceedings of an international symposium/workshop. Department of Geography Publication Series Occasional Paper No 11, University of Waterloo, Waterloo, p 61-68

Sargent NE (1988) Redistribution of the Canadian boreal forest under warmed climate. Clim Bull 22:23-34

Skmner WR, Gullett DW (1993) Trends of daily maximum and minımum temperature in Canada during the past century. Climatol Bull 27(2):63-75

Slaughter CW (1993) Global warming considerations in northern boreal forest ecosystems. In: Impacts of climate change on resource management in the north. Fourth Canada-United States Symposium \& Biennial AES/ DIAND Meeting on Northern Climate. Department of Geography, University of Waterloo, Waterloo, p 81-90

Sneyers R (1980) Foreword. Statistical climatology. Developments in atmospheric sciences 13. Proceedings of the First International Conference on Statistical Climatology. (A satellite meeting to the 1979 session of the ISI.) Elsevier Scientific Publication Co, Amsterdam, p i-v

Stuart RA, Judge AS (1991) On the applicability of GCM estimates to scenarios of global warming in the Mackenzie Valley Area. Climatol Bull 25(3):147-169

Wahl HE, Fraser DB, Harvey RC, Maxwell JB (1987) Climate of Yukon. Environment Canada, Atmospheric Environmental Service, Ottawa

Wall G (1990) Socio-economic implications of climate changes: Canadian climate impacts program study results. In: Climate change: implication for water and ecological resources. Proceedings of an international symposium/ workshop. Department of Geography Publication Series Occasional Paper No 11, University of Waterloo, Waterloo, p $69-78$

Wilkinson L (1990) SYSTAT: the system for statistics. SYSTAT, Inc, Evanston, IL

Woo MK, Lewkowicz AG, Rouse WR (1992) Response of the Canadian permafrost environment to climate change Phys Geogr 13(4):287-315 